\title{
Perbedaan Ekspresi FOXP3+ dan CD8+ Tumor Infiltrating Lymphocytes Karsinoma Payudara pada Berbagai Stadium T
}

\author{
Anisia Indiralia, Alphania Rahniayu, Sjahjenny Mustokoweni \\ Departemen/SMF Patologi Anatomi Fakultas Kedokteran Universitas Airlangga/RSUD Dr. Soetomo, Surabaya \\ Indonesia
}

\section{ARTICLE INFO}

\section{Article history}

Received 08 June 17

Received in revised form 22 January 18

Accepted 09 February 18

\section{Keywords:}

Tumor infiltrating lymphocytes, FOXP3, CD8, breast carcinoma, stage.

\section{Kata Kunci:}

Tumor infiltrating lymphocytes, FOXP3, $\mathrm{CD} 8$, karsinoma payudara, stadium

\begin{abstract}
Background: Breast carcinoma, the most common malignancy in women, are often accompanied by tumor infiltrating lymphocytes (TIL) which has controversial clinical relevance. TIL is thought to reflect the host's immune response to malignant tumors. FOXP3, specific biomarker of Treg, is an important transcription factors that develops and functions in the maintenance of self tolerance, including inhibition of CD8+ cytotoxic T cell function.
\end{abstract}

Aim: To analyze the differences and the correlation between FOXP3+ and CD8+ TIL in breast carcinoma with different T staging.

Methods: An analytical observational research, performed on 44 paraffin block of breast carcinoma of various stages T (AJCC $7^{\text {th }}$ ed) in anatomical pathology installation of RSUD Dr. Soetomo, used FOXP3+ and CD8+ antibodies. The immunoexpression are evaluated on stromal area, then analyzed statistically, period January 1, 2014 - December 31, 2016.

Result: Showed significant differences in FOXP3+ expression between T1-T4, T2-T3, T2-T4, T3-T4. There were significant differences in CD8+ expression between T2-T3, T2-T4. There is a correlation between the expression of FOXP3+ and CD8+ in T1 and all T $(p<0.05)$.

Conclusion: There was significant difference in FOXP3+ and CD8+ TIL of breast carcinoma with increasing T stage. There was correlation between FOXP3+ and CD8+ TIL expression of breast carcinoma at all $\mathrm{T}$ and $\mathrm{T} 1$ stage.

\section{ABSTRAK}

Pendahuluan: Karsinoma payudara adalah keganasan terbanyak wanita dan sering didapatkan adanya tumor infiltrating lymphocytes (TIL) dengan relevansi klinis yang masih kontroversial. TIL sering dianggap mencerminkan respon imun inang terhadap tumor ganas. FOXP3, biomarker spesifik Treg, merupakan faktor transkripsi yang penting dalam perkembangan dan berfungsi dalam pemeliharaan self tolerance, termasuk penghambatan fungsi sel T sitotoksik CD8+.

Metode: Penelitian observasional analitik terhadap 44 sampel blok parafin karsinoma payudara berbagai stadium T (AJCC edisi ketujuh) di instalasi Patologi Anatomi RSUD Dr. Soetomo Surabaya menggunakan antibodi FOXP3 dan CD8, dihitung pada area stroma tumor, kemudian dilakukan uji statistik periode 1 Januari 2014 - 31 Desember 2016.

Hasil: Terdapat perbedaan bermakna ekspresi FOXP3+ antara T1 dan T4, T2 dan T3, T2 dan T4, T3 dan T4. Terdapat perbedaan bermakna ekspresi CD8+ antara T2 dan T3, T2 dan T4. Terdapat korelasi antara tingginya ekspresi FOXP3+ dengan tinginya ekspresi CD8+ pada T1 dan semua $\mathrm{T}(\mathrm{p}<0,05)$.

Kesimpulan: Terdapat perbedaan bermakna ekspresi FOXP3+ dan CD8+ TIL karsinoma payudara dengan meningkatnya stadium T. Terdapat korelasi antara ekspresi FOXP3+ dan CD8+ TIL karsinoma payudara pada semua stadium T dan T1.
* Corresponding author: Anisia Indiralia Departemen / SMF Patologi Anatomi Fakultas Kedokteran Universitas Airlangga /RSUD Dr. Soetomo, Surabaya Email : nusantara_1427@yahoo.com 


\section{PENDAHULUAN}

Kanker payudara merupakan $23 \%$ dari seluruh neoplasma ganas wanita ${ }^{1}$. Di Indonesia angka kejadiannya $21,4 \%$ dari seluruh keganasan pada wanita². Sedangkan respon imun terhadap tumor sangat kompleks, sel imun dapat menghambat pertumbuhan tumor (immunoediting), tapi dapat juga meningkatkan pertumbuhan sel tumor dan angiogenesis. Immunoediting, yang terdiri dari 3 fase, yaitu fase eliminasi, fase equilibrium, dan yang terakhir fase escape Kehadiran TIL pada tumor diketahui dapat memberikan prognosis yang lebih baik. Infiltrasi limfosit disini termasuk sel T, Tregulatory (Treg), Natural Killer (NK) sel³.

Treg berperan dalam pencegahan penyakit auto imun, tetapi juga dapat menghambat imunitas anti tumor dan mempromosikan pertumbuhan tumor. Treg juga berperan dalam menghambat sel limfosit $\mathrm{T}$ sitotoksik dengan menghambat pelepasan granule dari CD8+, dimana CD8+ mempunyai peran penting dalam membunuh sel tumor. FOXP3 merupakan biomarker spesifik Treg, juga berperan penting dalam perkembangan dan fungsi dari Treg., ${ }^{4,5}$ Kehadiran FOXP3+ Treg menunjukkan hasil yang masih kontroversi. Penelitian pada beberapa tumor, adanya FOXP3+ menunjukkan prognosis yang buruk, sebaliknya penelitian pada tumor lain memperlihatkan prognosis yang baik. Pada karsinoma payudara, FOXP3+ TIL juga menunjukkan hasil yang berbeda, penelitian oleh Liu et al., Droser et al., Kim et al., menyatakan FOXP3+ TIL memberikan prognosis buruk, sebaliknya penelitian oleh West et al., menyatakan FOXP3+ TIL memberikan prognosis baik. ${ }^{4,5,6,7}$

Tujuan penelitian ini untuk menganalisis adanya ekspresi FOXP3+ TIL dan CD8+ TIL pada pasien dengan karsinoma payudara pada berbagai stadium $\mathrm{T}$.

\section{METODE PENELITIAN}

Rancangan penelitian menggunakan pendekatan cross sectional di instalasi Patologi Anatomi RSUD dr. Soetomo menggunakan blok parafin karsioma payudara di RSUD dr. Soetomo Surabaya, periode 1 Januari 2014-31 Desember 2016, secara random sampling pada kelompok T1, T2, T3 dan T4, dengan masing-masing 11 sampel, sehingga total sampel sebanyak 44 kasus. Dengan kriteria inklusi blok paraffin berasal dari jaringan tumor payudara yang diperoleh dari sediaan modified radical mastectomy, hasil pemeriksaan histopatologi sesuai dengan gambaran karsinoma payudara, memiliki stadium $\mathrm{T}$ yang dapat diukur, dan blok paraffin masih memiliki sel tumor yang cukup representatif untuk keperluan pemeriksaan immunohistokimia. Sedangkan untuk kriteria ekslusi adalah ter- dapat diagnosis keganasan tambahan selain karsioma pada sediaan tersebut, misalnya sarcoma atau phylloides.

Sampel penelitian (n) diperoleh dari rumus :

$$
\begin{aligned}
& \mathrm{n}=\left(\frac{\mathrm{z}_{1-\alpha / 2}+\mathrm{z}_{1-\beta}}{\frac{1}{2} \ln [(1+\mathrm{r}) /(1-\mathrm{r})]}\right)^{2}+3 \quad \begin{array}{l}
\alpha=0,05 \\
\beta=0,2
\end{array} \\
& \mathrm{Z}_{1-\alpha / 2}=1,96 \mathrm{Z}_{1-\beta}=0,84
\end{aligned}
$$

Dari penelitian sebelumnya diperoleh nilai $r=0,76^{7}$ Nilai n (sampel) minimal 11 blok paraffin

Penelitian menggunakan pulasan immunohistokimia FOXP3+ dan CD8+ pada blok parafin karsinoma payudara pada berbagai stadium T. FOXP3+ diperiksa dengan antibodi monoclonal FOXP3 (2A11G9) sc-53876 (Santa Cruz Biotechnology) dengan dilusi 1:50 dan terpulas positif pada inti TIL. CD8+ diperiksa dengan antibodi monoclonal CD8- $\alpha$ (0.N.66) sc-70791 (Santa Cruz Biotechnology) dengan dilusi 1:100 dan terpulas positif pada membran sel TIL. Ekspresi FOXP3+ dan CD8+ dihitung dari rata-rata 5 lapang pandang 400x HPF, pada area stroma tumor (area diluar dari pulau sel tumor dan area diantara pulau sel tumor didalam area tumor). ${ }^{7,11}$

Analisa data menggunakan SPSS untuk mengetahui perbedaan ekspresi FOXP3+ pada kelompok T1, T2, T3, dan T4 digunakan uji statistik Kruskal Wallis dan Mann Whitney. Untuk mengetahui perbedaan ekspresi CD8+ pada kelompok T1, T2, T3, dan T4 digunakan uji statistik Brown-Torsythe dan Games-Howell. Untuk mengetahui korelasi antara FOXP3 dengan CD8 pada berbagai stadium $\mathrm{T}$ digunakan uji statistik dengan uji korelasi Pearson jika data terdistribusi normal dan uji korelasi Spearman jika data tidak terdistribusi dengan normal. Uji statistik bermakna jika $\mathrm{p}<0,05$.

Penelitian ini telah mendapatkan keterangan kelaikan etik (ethical clearance) dengan nomor: 252/Panke.KKE/ IV/2017.

\section{HASIL}

Uji analisis statistik Kruskal-Wallis, didapatkan hasil $p=0,000$, terdapat perbedaan yang signifikan antara ekspresi FOXP3+ pada T1, T2, T3, dan T4. Sedangkan dengan Mann Whitney untuk perbedaan pada tiap kelompok, terdapat perbedaan yang bermakna pada ekspresi FOXP3+ antara kelompok sampel T1 dan T4 dengan nilai $p=0,002$, antara kelompok sampel T2 dan T3 dengan nilai $p=0,007$, antara kelompok sampel T2 dan T4 dengan nilai $p=0,000(p<0,05)$, dan antara kelompok sampel T3 dan T4 dengan nilai $p=0,017$. 
Tabel 1. karakteristik kliniko patologi pasien

\begin{tabular}{lcc}
\hline Parameter & Frekuensi & Persentase (\%) \\
\hline Usia & & \\
$\leq 40$ & 8 & 18,2 \\
$41-50$ & 13 & 29,5 \\
$51-60$ & 15 & 34,1 \\
$>60$ & 8 & 18,2 \\
\hline Jenis & & \\
Histopaologi & 1 & 2,3 \\
Cribiform Ca & 34 & 77,3 \\
IDC & 6 & 13,6 \\
ILC & 1 & 2,3 \\
Mixed IDC ILC & 1 & 2,3 \\
Mucinous Ca & 1 & 2,3 \\
Papillary Ca & & \\
\hline Grade & 5 & 11,4 \\
I & 18 & 40,9 \\
II & 21 & 47,7 \\
III & & \\
\hline Stadium N & 10 & 22,7 \\
NO & 14 & 31,8 \\
N1 & 9 & 20,5 \\
N2 & 10 & 22,7 \\
N3 & 1 & 2,3 \\
Nx & & \\
\hline & &
\end{tabular}

Tabel 2. Distribution Distribusi karsinoma payudara berdasarkan ekspresi FOXP3+

\begin{tabular}{|c|c|c|c|c|c|c|c|}
\hline \multirow{2}{*}{$\begin{array}{c}\text { Stadium } \\
\mathbf{T}\end{array}$} & \multirow{2}{*}{$\mathbf{N}$} & \multicolumn{5}{|c|}{ Ekspresi FOXP3+ } & \multirow{2}{*}{$\mathbf{P}$} \\
\hline & & $\bar{x}$ & SD & Median & Min & Max & \\
\hline $\mathrm{T} 1$ & 11 & $45,92^{b c}$ & 26,26 & 40,20 & 10,00 & 80,00 & \multirow{4}{*}{$0,000 *$} \\
\hline $\mathrm{T} 2$ & 11 & $66,28^{c}$ & 16,72 & 71,33 & 20,07 & 78,67 & \\
\hline T3 & 11 & $39,37^{b}$ & 24,81 & 42,67 & 11,00 & 78,67 & \\
\hline $\mathrm{T} 4$ & 11 & $14,85^{a}$ & 8,76 & 12,40 & 3,47 & 30,00 & \\
\hline
\end{tabular}

*signifikan pada $\alpha=0,05$ (Kruskal-Wallis test)

abc superscript yang sama menunjukkan tidak ada perbedaan antar kelompok (Mann-Whitney test)

\section{Ekspresi FOXP3+}

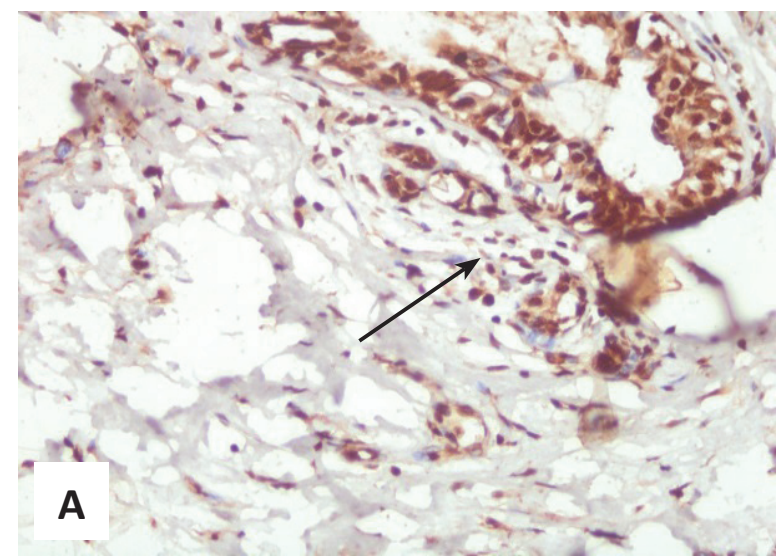

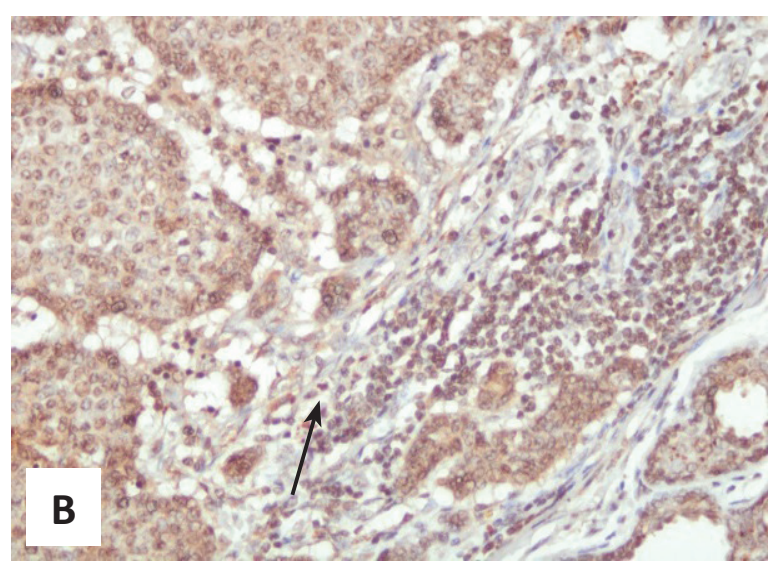
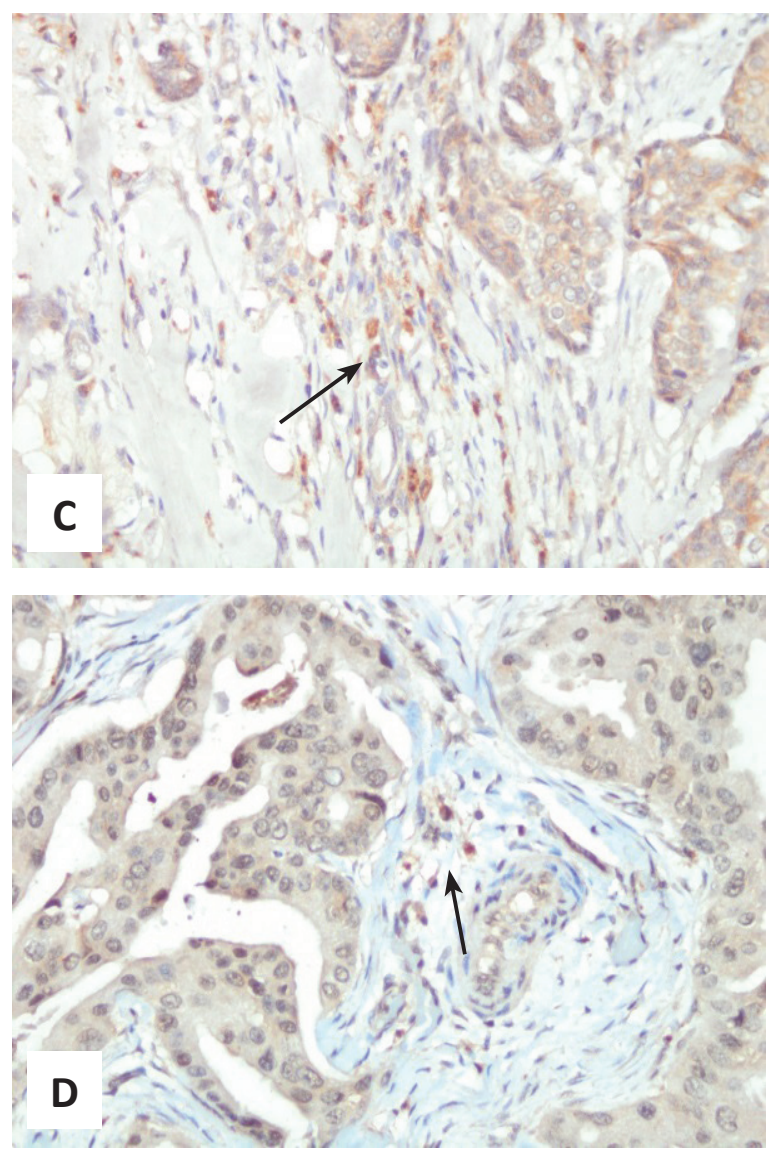

Gambar 1. Ekspresi FOXP3+ TIL pada karsinoma payudara (imunohistokimia, 400x).

A. Ekspresi FOXP3+ TIL karsinoma payudara pada stadium T1.

B. Ekspresi FOXP3+ TIL karsinoma payudara pada stadium T2 .

C. Ekspresi FOXP3+ TIL karsinoma payudara pada stadium T3.

D. Ekspresi FOXP3+ TIL karsinoma payudara pada stadium T4 
Tabel 3. Distribusi karsinoma payudara berdasarkan ekspresi CD8+

\begin{tabular}{|c|c|c|c|c|c|c|}
\hline \multirow{2}{*}{$\begin{array}{c}\text { Stadium } \\
\mathbf{T}\end{array}$} & \multirow{2}{*}{$\mathbf{N}$} & \multicolumn{4}{|c|}{ Ekspresi FOXP3+ } & \multirow{2}{*}{$\mathbf{P}$} \\
\hline & & $\bar{x}$ & SD & Min & Max & \\
\hline $\mathrm{T} 1$ & 11 & $40,34^{\mathrm{ab}}$ & 23,80 & 10,40 & 78,00 & \multirow{4}{*}{0,000} \\
\hline $\mathrm{T} 2$ & 11 & $57,67^{b}$ & 12,62 & 38,33 & 78,67 & \\
\hline T3 & 11 & $29,49^{a}$ & 11,49 & 17,73 & 53,33 & \\
\hline T4 & 11 & $21,07^{a}$ & 10,26 & 10,00 & 39,33 & \\
\hline
\end{tabular}

*signifikan pada $a=0,05$ (Statistik Brown-Forsythe)

${ }^{a b}$ superscript yang sama menunjukkan tidak ada perbedaan antar kelompok (multiple comparisons Games-Howell)

Analisis statistik menggunakan Brown-Forsythe, didapatkan hasil $p=0,000$, terdapat perbedaan yang signifikan antara ekspresi CD8+ pada T1, T2, T3, dan T4. Sedangkan uji statistik dengan Games-Howell untuk mengetahui perbedaan pada tiap kelompok, terdapat perbedaan yang bermakna pada ekspresi CD8+ antara kelompok sampel pada T2 dan T3 dengan nilai $\mathrm{p}=0,000$, dan antara kelompok T2 dan T4 dengan nilai $p=0,000$.

\section{Ekspresi CD8+}
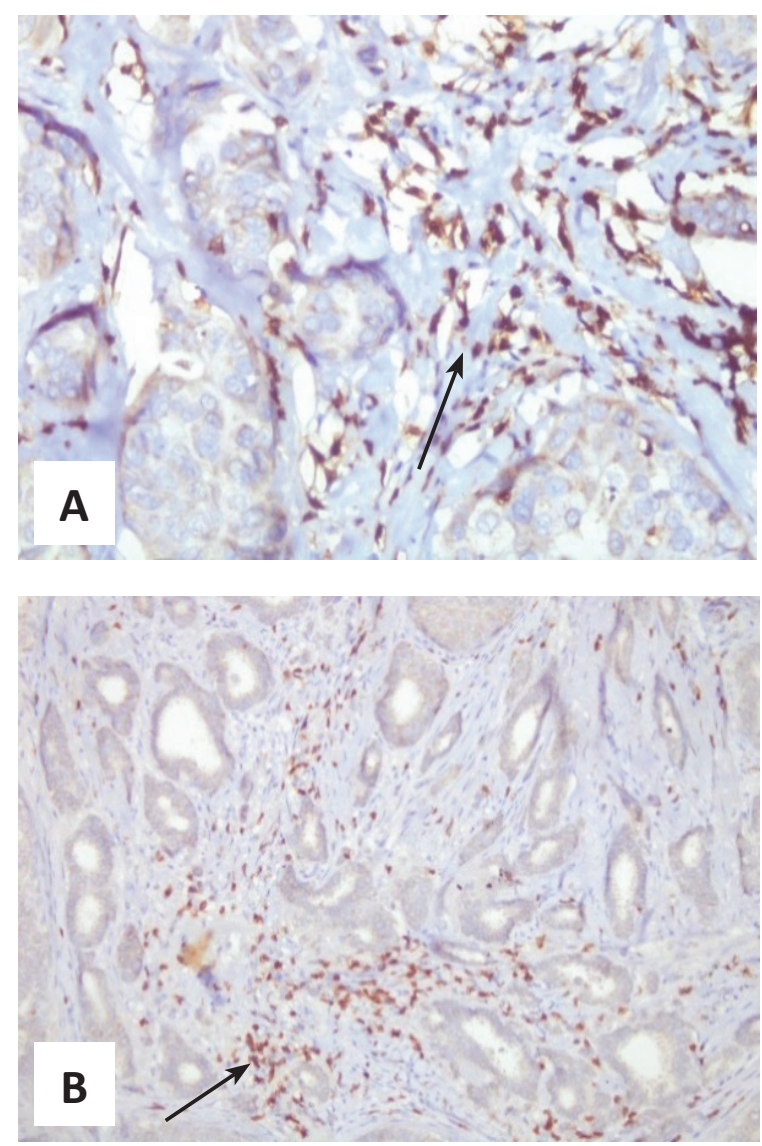
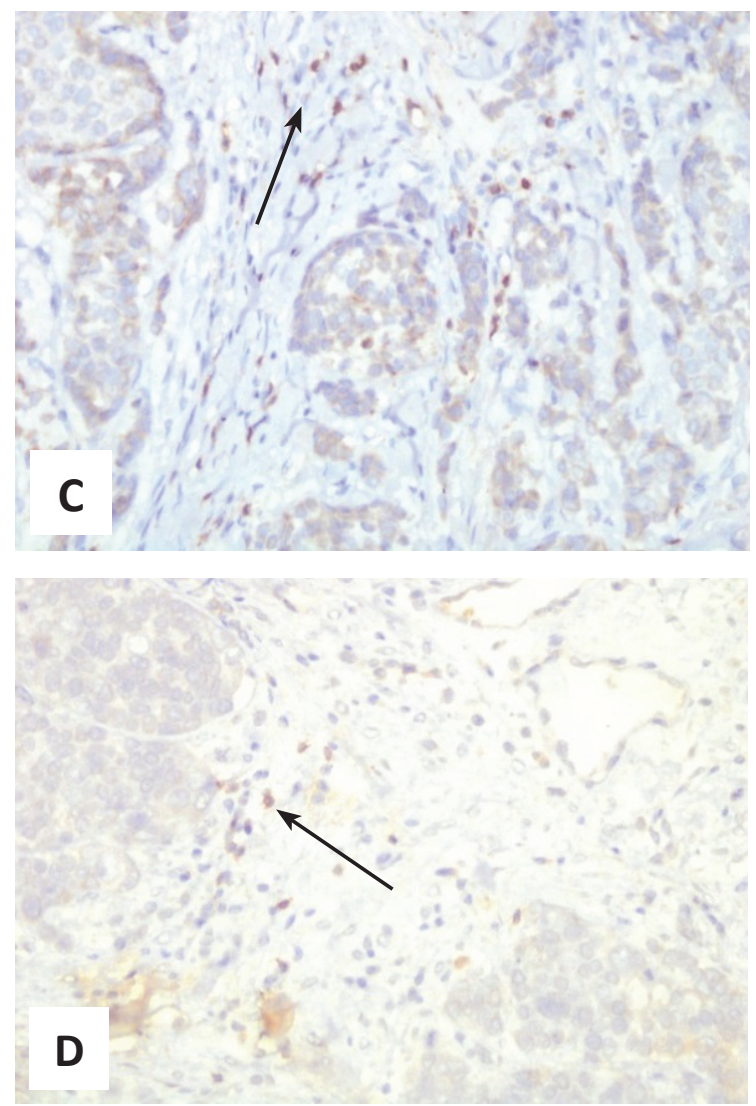

Gambar 2. Ekspresi CD8+ TIL pada karsinoma payudara.

A. Ekspresi CD8+ TIL karsinoma payudara pada stadium T1 (pembesaran 400x).

B. Ekspresi CD8+ TIL karsinoma payudara pada stadium T2 (pembesaran 200x).

C. Ekspresi CD8+ TIL karsinoma payudara pada stadium T3 (pembesaran 400x).

D. Ekspresi CD8+ TIL karsinoma payudara pada stadium T4 (pembesaran 400x).

Korelasi ekspresi CD8+ dan FOXP3+ TIL karsinoma payudara pada berbagai stadium $\mathrm{T}$, diuji dengan uji korelasi Pearson jika data terdistribusi normal dan uji korelasi Spearman jika data tidak terdistribusi dengan normal, dapat dilihat pada tabel 4 .

Tabel 4. Korelasi ekspresi CD8+ dengan FOXP3+ pada karsinoma payudara

\begin{tabular}{ccc}
\hline \multirow{2}{*}{ Stadium } & \multicolumn{2}{c}{ Korelasi Ekspresi CD8+ dengan FOXP3+ } \\
\cline { 2 - 3 } & Koefisien korelasi & $\mathbf{p}$ \\
T1 & $r=0,824$ & $0,002^{*}$ \\
T2 & $r_{s}=0,469$ & 0,146 \\
T3 & $r=0,319$ & 0,340 \\
T4 & $r=0,403$ & 0,219 \\
\hline Semua T & $r_{s}=0,714$ & $0,000^{*}$ \\
\hline
\end{tabular}

*signifikan pada $\alpha=0,05$

( $r$ = koefisien korelasi Pearson, $r_{s}=$ koefisien korelasi Spearman) 
Hasil analisa uji korelasi Pearson didapatkan adanya korelasi positif yang signifikan antara ekspresi CD8+ dengan ekspresi FOXP3+ pada stadium T1TIL karsinoma payudara dengan hasil $r=0,824$ dengan nilai $p=0,002$ $(p<0,05)$. Sedangkan analisa dengan uji korelasi Spearman didapatkan adanya korelasi positif yang signifikan antara ekspresi CD8+ dengan ekspresi FOXP3+ pada semua stadium T TIL karsinoma payudara dengan hasil $r_{s}=0,714$ dengan nilai $p=0,000(p<0,05)$. Sehingga pada stadium $\mathrm{T} 1$ dan stadium semua $\mathrm{T}$ terdapat korelasi positif yang bermakna antara ekspresi FOXP3+ dan CD8+.

\section{PEMBAHASAN}

\section{Karakteristik Sampel Penelitian}

Penelitian ini terdiri dari 44 blok parafin karsinoma payudara, semuanya berjenis kelamin wanita, dengan rentang usia terbanyak 51-60 tahun. Berdasarkan gambaran histopatologis terbanyak adalah IDC (Infiltrating Ductal Carcinoma) yaitu sebanyak 34 pasien (77,3\%), dengan derajat differensiasi (grading) paling banyak grade III, sebanyak 20 pasien (45,5\%), dan stadium N paling banyak adalah $\mathrm{N} 1$, yaitu sebanyak 14 pasien (31,8\%).

\section{Ekspresi FOXP3+ pada Tumor Infiltrating Lymphocyte (TIL) karsinoma payudara dengan berbagai stadium T (T1, T2, T3, T4).}

FOXP3 gen X-linked adalah anggota dari keluarga forkhead box/winged-helix faktor transkripsi meliputi perkembangan dan fungsi regulasi sistem imun. ${ }^{12}$ Pada penelitian ini dilakukan pemeriksaan immunohistokimia untuk melihat ekspresi FOXP3+ TIL karsinoma payudara pada masing-masing kelompok berbagai stadium $\mathrm{T}$, dengan menggunakan antibodi monoklonal FOXP3+, yang dinilai berdasarkan persentase jumlah sel tumor yang tercat positif pada inti sel limfosit pada area stroma tumor.

Pada penelitian ini didapatkan hasil, dimana ukuran tumor > 2-5 cm (T2) memiliki presentasi FOXP3+ paling tinggi kemudian diikuti ukuran tumor $\leq 2 \mathrm{~cm}$ (T1) kemudian ukuran tumor $>5 \mathrm{~cm}$ (T3) dan terakhir T4, ini sesuai dengan penelitian yang dilakukan oleh Frey et al dan Liu et al.. ${ }^{4}$

Terjadinya karsinoma itu sendiri memerlukan suatu perjalanan dan banyak faktor imunitas, dimana fase awal (fase eleminasi) sistem imun innate dan adaptive berkerjasama untuk mendeteksi dan menghancurkan sel karsinoma sebelum muncul secara klinis, peran keseimbangan respon imun anti tumor seperti sel T CD8+, sel T CD4, sel NK dan sel NKT dibutuhkan, sehingga CD8+ keberadaanya tinggi pada fase awal. Seiring dengan perjalanan tumor, DC (Dendritic Cell) dapat memproduksi Treg dan sel tumor itu sendiri dapat merekrut dan menstimulasi sel Treg dengan mensekresi TGF- $\beta$ dan CCL-2, dalam penelitian ini FOXP3+ merupakan biomarker dari Treg. Sehingga pada fase equilibrium terjadi keseimbangan antara faktor anti tumor dan fase promoting tumor. FOXP3+ berperan penting selama seleksi CD8+. Treg juga berperan dalam menghambat APC (DC), CD8+, NK dan CD4+, yang akan menghambat pengenalan sel imun, sehingga menyebabkan kanker terus berkembang pada fase akhir atau fase escape. Ketika DC juga dihampat maka pada fase lanjut ini konsentrasi Treg juga akan turun. ${ }^{3}$ Seperti pada penelitian kali ini didapatkan hasil pada tumor-tumor stadium awal atau T1 ekspresi dari FOXP3 tinggi, kemudian meningkat pada stadium T2, ini dapat disebabkan karena pada awal FOXP3+ masih banyak diproduksi dan setelahnya menurun pada stadium lanjut (T3 dan T4) dapat disebabkan karena sel imun sendiri yang banyak dihambat sehingga Treg sendiri menurun produksinya.

\section{Ekspresi CD8+ pada Tumor Infiltrating Lymphocyte (TIL) karsinoma payudara dengan berbagai stadium $T$ (T1, T2, T3, T4)}

CD8 (Cluster of Differentiation 8) adalah glikoprotein yang berfungsi sebagai co-reseptor untuk $T$ Cell Reseptor (TCR). CD8 mengikat molekul Major Histocompatibility Complex (MHC) spesifik untuk protein MHC kelas I. CD8 berfungsi sebagai Cytotoxic $T$ Lymphocytes (CTL) yang akan menghancurkan sel inang mikroba. Sel T sitotoksik ini merupakan limfosit $\mathrm{T}$ yang dapat membunuh sel kanker. ${ }^{3,9}$

Telah disebutkan bahwa ada fase eleminasi dimana keseimbangan respon imun anti tumor seperti sel T CD8+, sel T CD4, sel NK dan sel NKT dibutuhkan, terutama sel T CD8+ dapat melisis sel karsinoma secara langsung, atau melalui sel T CD4 yang mengenali APC melalui MHC ॥ dan membuat sel T CD8 melalui TCR akan membentuk kompleks dengan APC melalui MHC I, sehingga CTL menghasilkan granzym, porfirin dan interferon $\gamma$ menyebabkan granule exocytosis dan menyebabkan kematian sel melalui apoptosis. Fase equilibrium terjadi keseimbangan antara faktor anti-tumor dan tumorpromoting tumor. Pada fase escape sel karsinoma dapat lepas dari sistem imun, termasuk penurunan pengenalan melalui penurunan ekspresi MHC I dan peningkatan faktor imunosupresif, dimana pada aktivasi yang terusmenerus dan berkepanjangan sel T CD8+ terjadi kelelahan, maka CTLA-4, TIM-3 dan PD-1 pada CD8+ akan memberikan sinyal penghambatan. ${ }^{3}$ Sehingga dapat dilihat 
bahwa pada tumor dengan stadium awal ekspresi CD8+ didapatkan tinggi dan akan meningkat pada stadium T2, kemudian akan menurun pada stadium akhir (T3 dan T4), hal ini dapat disebabkan karena CD8+ telah terjadi kelelahan karena aktivasi yang terus menerus dan dapat juga pada fase akhir ini CD8+ telah banyak dihambat oleh FOXP3+.

\section{Korelasi ekspresi CD8+ dengan FOXP3+ pada Tumor Infiltrating Lymphocyte (TIL) karsinoma payudara}

Penelitian oleh West et al., menyebutkan bahwa FOXP3+ TIL sangat berkorelasi dengan tingginya tingkat $\mathrm{CD} 8+\mathrm{TIL}^{7,10}$ hal ini sesuai dengan hasil penelitian saat ini.

Sel T CD8+ dan Treg dapat menyusup ke tumor menggunakan mekanisme yang serupa. Ekstravasasi sel T dimulai dengan rolling vascular dan berinteraksi dengan endothelial selectin, yang diekspresikan oleh Treg dan sel T CD8+ yang diaktifkan. Kemokin pada lumen vaskular kemudian mengaktifkan molekul adhesi limfosit untuk mempromosikan terjadinya ekstravasasi. Disini mayoritas reseptor kemokin yang memediasi ekstravasasi sel T CD8+ juga diekspresikan oleh sel T FOXP3+. Dengan demikian, FOXP3+ dan CD8+ TIL keduanya dapat bersama-sama menginfiltrasi pada karsinoma payudara. Sehingga keberadaannya dapat ditemukan bersamaan pada karsinoma payudara. ${ }^{7}$ Seperti halnya penelitian kali ini, didapatkan korelasi positif antara tingginya FOXP3+ dan CD8+.

Keterbatasan dalam penelitian ini dalam hal ketersediaan data stadium klinis, data kadar serum darah, terapi yang diberikan sebelum MRM, belum ada metode yang standar dalam perhitungan, serta kontrol proses pembuatan preparat yang masih kurang.

Berdasarkan hasil penelitian: terdapat perbedaan ekspresi FOXP3+ TIL antar stadium T karsinoma payudara. FOXP3+ TIL terekspresi lebih tinggi pada stadium T2 (ukuran tumor $>2 \mathrm{~cm}$ sampai $<5 \mathrm{~cm}$ ), kemudian menurun pada stadium T3 (ukuran tumor $>5 \mathrm{~cm}$ ) dan T4 (tumor dengan berbagai ukuran dengan ulkus dan skin nodule), terdapat perbedaan ekspresi CD8+ TIL antar stadium T karsinoma payudara. CD8+ TIL terekspresi lebih tinggi pada stadium T2 (ukuran tumor $>2 \mathrm{~cm}$ sampai $<5 \mathrm{~cm}$ ), kemudian menurun pada stadium T3 (ukuran tumor $>5 \mathrm{~cm}$ ) dan T4 (tumor dengan berbagai ukuran dengan ulkus dan skin nodule), terdapat hubungan positif antara ekspresi FOXP3+ dan CD8+ TIL karsinoma payudara pada stadium T1 dan stadium T1 secara keseluruhan.

Penelitian ini dapat membantu memprediksi prognosis karsinoma payudara, sehingga dapat membantu klinisi dalam terapi dan prognosis pasien.

\section{UCAPAN TERIMA KASIH}

Penulis mengucapkan puji syukur kehadirat Allah SWT, penulis juga menyampaikan rasa terima kasih sedalamdalamnya kepada Sjahjenny Mustokoweni, dr., Sp.PA(K), MIAC, Alphania Rahniayu, dr., Sp.PA selaku pembimbing yang telah banyak memberikan arahan serta bimbingan dan juga kepada guru-guru kami dan berbagai pihak yang telah memberikan bantuan dan dukungan sehingga penelitian ini dapat diselesaikan. Peneliti tidak memiliki permasalahan dalam pembuatan penelitian ini.

\section{KESIMPULAN}

Terdapat perbedaan ekspresi FOXP3+ TIL karsinoma payudara pada setiap stadium $\mathrm{T}$ dan terdapat perbedaan ekspresi CD8+ TIL karsinoma payudara pada setiap stadium T. Terdapat peran dan hubungan antara ekspresi FOXP3+ dan CD8+ TIL karsinoma payudara pada keseluruhan stadium T. Sehingga keberadaan dari FOXP3+ dan CD8+ mempunyai peranan pada karsinoma payudara dengan prognosa yang lebih baik.

Berdasarkan hasil dan pembahasan penelitian, maka disarankan: perlu dilakukan penelitian lanjutan menggunakan antibodi FOXP3+ dan CD8+ pada karsinoma payudara dengan kelengkapan data stadium klinis, data terapi yang telah diberikan sebelum MRM, kadar serum darah dan dilakukan perhitingan rasio antara FOXP3+ dan CD8+, perlu dilakukan penelitian prospektif lanjutan dengan marker TIL lain, contoh dengan CD4Th1, CD4 Th2 untuk memperjelas peran TIL pada karsinoma payudara secara keseluruhan dan penelitian TIL terkait dengan subtipe molekular dari karsinoma payudara, penelitian lanjutan dengan pasien MRM dengan karsinoma yang sejenis.

\section{DAFTAR PUSTAKA}

1. Lakhani SR, Ellis IO, Schnitt SJ, Tan PH, van de Vijver MJ, editors. World Health Organization Classifications of Tumors of the Breast. $4^{\text {th }}$ ed. Lyon: International Agency for Research on Cancer. 2012; $4^{\text {th }}$ ed.

2. World Health Organization. Cancer Country Profiles. 2014.

3. Dushyanten S, Beavis PA, Savas P, Teo ZL, Zhou C, Mansour PKD, Loi S. Relevance of tumot infiltrating lymphocytes in breast cancer. BMC medicine. 2015; 13:202.

4. Liu S, Foulkes WD, Leung, Gao D, Lau S, Kos Z, Nielson TO. Prognostic significance of FOXP3+ tumor-infiltrating lymphocytes in breast cancer depends on estrogen receptor and human epidermal growth factor receptor-2 expression 
status and concurrent cytotoxic T-cell infiltration. Breast Cancer Research. 2014; 16:432.

5. Kim S, Lee A, Lim W, Park S, Cho MS, Koo H, Moon BI, Suung SH. Zonal Differencee Prognostic Significancee of Foxp3 Regulatory T Cell Infiltration in Breast Cancer. Journal of Breast Cancer. 2014;17(1):8-17

6. Droser R, Zlobec I, Kilic E, Guth U, Heberer M, Spagnoli G, Oertli D dan Tapia C. Differential pattern and prognostic significance of CD4+, FOXP3 + and IL-17+ tumor infiltrating lymphocytes in ductal and lobular breast cancers. BMC cancer. 2012; 12:134

7. West NR, Kost SE, Martin SD, Milne K, deLeeuw RJ, Nelson $\mathrm{BH}$ dan Watson $\mathrm{PH}$. Tumour-infiltrating FOXP3+ lymphocytes are associated with cytotoxic immune responses and good clinical outcome in oestrogen receptor-negative breast cancer. British Journal of Cancer. 2013; 108, 155-162
8. Salgado R, Denkert C, Demaria S, Sirtaine N, Klauschen F, Pruneri G, Wienert S, Van Den Eyden G, Baehner FL, Penault-Llorca F, Perez EA, Thompson EA, Symmans WF, Richardson AL, Brock J, Criscitiello C, Bailey $H$, Ignatiadis $M$, Floris G, Sparano J, Kos Z, Nielsen T, Rimm DL, Alison KH, Reis-Gilho JS, Loibi S, Sotiriou C, Viale G, Badve S, Adams S, Williard-Gallo $\mathrm{K}$ dan Lou S. The evaluation of tumorinfiltrating lymphocytes (TILS) in breast cancer: recommendations by an International TILs working Group 2014. Annals of Oncology. 2014; 26:259-271.

9. Kumar V, Abbas A, Aster J. Robbins and Cotran Pathologic Basis of Disease. $9^{\text {th }}$ edition. Philadelphia: Saunders Elsevier. 2015; Page 1052-1053

10. Mhawech-Faeceglia P, Wang D, Ali L, Lele S, Huba MA, Liu $S$ dan Odunsi K. Intraepithelial T cells and tumor-associates macrophages in ovarian cancer patients. Cancer Immunity (15 january 2013). 2013; Vol.13, p.1. 